\title{
Effect of Brand Equity on Consumer Buying Behavior of Huawei Brand in Colombo Area
}

\author{
G.J.H. Chithrasekara ${ }^{1} \&$ T.K. Karandakatiya ${ }^{2}$ \\ ${ }^{1,2}$ Department of Business Management \\ Faculty of Business Studies \& Finance \\ Wayamba University of Sri Lanka \\ Kuliyapitiya \\ SRI LANKA \\ Jchithrasekara@gmail.com ${ }^{1}$, thusithakk@wyb.ac.lk ${ }^{2}$
}

\begin{abstract}
Huawei is the second largest mobile vendor in Sri Lanka which is looking for a better brand equity in the marketplace. With the emergence of mobile vendors such as Samsung and Apple, the competition was arisen. Samsung is a global digital technology leader in Sri Lanka and building of Samsung mobile phones with new lines and providing competitive offers on mobile phone plans to local Customers. With the increase of the disposable income, it will lead to increase the competition in the smartphone industry. However, there is a growing bad image on Huawei due to the effect of the recent ban of Huawei by US in their market. It is likely to create a problem of increasing sales in the 2020 in the Sri Lankan market. This study therefore aimed at identifying the impact of brand equity on consumer buying behavior based on Huawei in Colombo area. It is therefore crucial to understand brand equity as it affects the purchasing decisions of the customers due to the past experience with the product usage, familiarity with brand and its characteristics. Pursuant to this, objectives of the present study were formulated and they were to identify the impact of selected brand equity dimensions and to identify the overall impact of brand equity on consumer buying behavior of Huawei in Colombo area. The study was based on the Brand equity model developed by Aeker(1991). Based on that, hypothesis were formed to find out whether there is a positive impact of brand awareness, brand association, brand loyalty, perceived quality, and brand equity as a whole on consumer buying behavior. They were tested using multiple regression analysis. A sample of 380mobile users in Mattakkuliya and Jinthupitiya area in Sri Lanka were contacted using convenience sampling technique and a questionnaire was selfadministrated. Analysis of data revealed that there is a positive impact of brand awareness, brand association, brand loyalty, perceived quality and brand equity on consumer buying behavior. The present study can be further extended by including foreign countries with larger samples.
\end{abstract}

Keywords: Brand Association, Brand Awareness, Brand Loyalty, Consumer Buying Behavior, Perceived Quality 


\section{INTRODUCTION}

In the telecommunication industry, mobile industry is the fastest growing market (Cecere, et.al, 2014). Mobile phones are becoming a part of the information and communication technology sector and it is an innovative part(Hossain \& Ahmed, 2018, p. 1). In the year 2021 the mobile phones will be 3.5 billion while it was forecasted that there will 7.26 billion growth in the mobile users (O'Dea, 2020). With the emergence of mobile vendors such as Samsung and Apple, the competition was arisen. Samsung is the large mobile vendor of Sri Lanka and started its operation in 2004. Their objective was to become more competitive in the market through innovative Samsung products with new lines, to provide Samsung products with better brand presence, better product portfolio, which are having different mobile plans, broader networks of channels and networks. According to Cecere et, al. (2014) the recent battle over patents and designs between Apple and Samsung vendors indicated that smartphone makers in the market are having large competition for the leadership in the market. In local context, $50 \%$ of the population are using mobile phones and as that rate is considerable when compared to developing countries there is a growing trend in using mobile services (Businesswire,2016). As there is a growing trend for mobile services and mobile vendors it has a positive impact on Sri Lankan government sector. Service sector plays a major role in GDP of Sri Lanka.According to the findings there was a subscriber base of 17.2 million for every 100 people with 100.79 people who had both wireless connections (Central Bank: 2010). So, analyzing consumer behavior with reference to the mobile phones has been important and this study was focused on examine the impact of selected brand equity dimensions and overall brand equity impact on consumer buying behavior of Colombo. Brand equity is a marketing concept in order to face the competition. It is an important marketing tool for businesses for the survival (Keller, 2013). According to Lee, et al(2016) brand equity is based on assets and liabilities those assets and liabilities can be classified into five categories according to Aeker (1991). They are brand loyalty, brand awareness, perceived quality and brand association. Brand equity creates a value for businesses and customers. From customer point of view, brand equity supports customers to interpret process and store high qualities of information about products and brand. From the company perspective, brand equity is important for financial aspects, strategy motivation and to increase the marketing productivity. Thus, the need for marketers to gain a better understanding of brand equity in terms of consumer buying behavior is crucial.

With the increase of the disposable income it will result an increase in the competition in the smartphone industry. According to the Department of Census and Statics of Sri Lanka, disposable income has increased over the years. In the year 2017, household per capita income increased by 35.7 $\%$.With the increase of the competition, smartphone companies 
are leveraging their brands by enhancing marketing strategies and providing variety of products to retain and attract new customers (Chen \& Chen 2011). Technological innovations play an important role in the industry of mobile and telecommunication are now expanding it in the area of mobile phone technologies. So that, mobile phones which are based on technologies are now something rather than consumer needs and wants. Apart from that, as there are many mobile phone manufacturers in the industry, there is a huge competition. The market share of mobile vendors like Samsung, Huawei, and Apple has been increased from 2018 to 2019 by $43.84 \%-43.66 \%, 23.91 \%-24.65 \%$ and $7.24 \%-9.11 \%$ respectively. With the Huawei ban in US and due to Google cuts off Huawei phones from future android updatesin 2019, executives announced that there will be a sales drop in the year 2020. During the previous year Huawei brand had increased their sales by $19.1 \%$ and with a market share of $25.47 \%$ in 2020.In the first half of the 2018 market share of the Huawei mobile phones was $41 \%$ and at the end of the 2019 it was 36.5\%. In 2013 market share of Huawei was $7 \%$ and within two years it doubled market share up to $15.3 \%$. These findings shows that Huawei is becoming the fastest Growing smart phone Brand in the local market(Daily mirror, 2018).Therefore, Huawei is currently performing well and have a problem of increasing sales with recent ban, increasing household income and competition. Internationally, researches have conducted on impact on consumer buying behavior in different industries such as for L'Oreal skin care products (Akhtar et, al.2016), fast moving consumer goods and impact on packaging, price impact of individual components of brand equity. In local context, a research conducted on impact of brand equity on preference reference to motor vehicle industry(Nilmini,2014), and impact of brand equity towards purchasing decision with reference to the mobile telecommunication services of Sri Lanka (Gunawardhana, 2015). Studies are rare in Sri Lanka because it is an emerging trend in Sri Lanka. Therefore, this study will explore the impact of brand equity on consumer buying behavior based on Huawei brand in Colombo area.

\subsection{Consumer Buying Behavior}

When analyzing these existing literatures regarding the consumer buying behavior, the most recent and commonly used definition that best describes the consumer buying is how individuals, groups or organizations choose, buy use and dispose he goods and the factors such as their previous experience, taste, price and branding on which the consumers base their purchasing decisions (Kotler and Keller, 2012). From the company perspective, analyzing consumer buying behavior becoming crucial for a mobile vendor for two reasons, it can be identified as increasing market shares of mobile vendors and increasing mobile subscriber base. In the marketing process, marketing managers and the sales persons plays a vital role. Consumers are the most important person to them, so their likes and dislikes are important to offer a better product or a service that 
suitable for them (Madichie, 2009). So study on consumer buying behavior allow business managers and sales persons to design the best product that satisfy consumer needs and wants, to decide the easy access way to the product or the service and finally to decide the best price affordable to the customers as the markers design their products in such way that the product gives maximum value or features to consumers at affordable price (Goessl, 2011). From the sales perspective, according to the Coldwell (2001) there is a positive relationship between consumer satisfaction and profitability. Consumer satisfaction was taken in to consideration because it drives consumer buying behaviors such as shopping frequently, higher expenditures and suggesting targets. Theory of Reasoned Action studies about the consumer behavior which is a psychological model. According to this theory consumer buying behavior is affected by behavioral intention and intention comes from attitude of a consumer which consumer buying behavior depends. (Claiborne \& Sirgy, 2014). Technology Acceptance Model (TAM) best describes consumer buying behavior with introduction of a new information technology. According to this theory, two factors were discussed and they were perceived usefulness and perceived ease of use (Nasri \& Lanouar, 2012). The mentioned measures of consumer buying behavior according to the Baumgartner \& Steenkamp (1996) perspective were product acquisition and information seeking (Taylor, 2012).

\subsection{Brand Equity}

Brand equity theories started to develop in 1980 and Brand Equity is an important aspect of branding which leads to organizational success. Definition of brand equity concept is based on three perspectives. It is Consumer based, financial based and employee based. Brand equity is a set of assets and liabilities linked to the memory of the brand its name and symbols that add value to or subtract value from product or service according to Aeker (1991). Fieldwork (1996) and Leuthesser (1998) defined brand equity through several perspectives. Many definitions on Brand Equity are available, Aeker (1991) and Keller's brand equity model is popular in the area. The reason for this was the other definitions of brand equity give a narrow perception. Aeker's model, Keller's model, Brand asset valuator, and Brandz model are several models identified through the available literature on brand equity. Based on Components of brand equity model of Aeker brand awareness, brand association, brand loyalty and perceived quality are the measurements of brand equity.

\subsection{Brand Equity and Consumer Buying Behavior}

Impact of Brand equity on consumer buying behavior can be measured though many dimensions. Aeker's model stated brand association, brand awareness, brand loyalty and perceived quality used to measure consumer buying behavior. Further Aeker (1991) describes brand equity as one of the closer variable to the 
consumer buying behavior decision making process. Another dimension category was brand resonance, brand performance and imaginary, brand salience according to Keller's model. Brand asset valuator model introduced by advertising agency consisted with five dimensions, differentiation, energy, relevance, esteem and knowledge. Milward Brown and WPP Company has introduced Brandz model as a series of 6 interrelated steps. Aeker's brand equity concept dimension of Brand association is inductive of consumer attributes towards a brand and it represents the reasons to purchase and it represent brand loyalty. Perceived quality shape the consumer buying behavior because people may perceive quality in many ways. Perceived quality shape the consumer buying behavior as people may perceive quality in many ways.

Aeker (1991) stated such three levels of analysis. They are consumers firstly perceive a product quality as low, medium or high. As the second, people may perceive it as a relative in quality. Finally it can be because of the consistency and inconsistency of a product. Therefore according to this high perceived quality would determine the consumer brand choice and increase brand equity (Aaker 1991). According to Yoo et, al., (2000) marketers should understand brand equity attributes and the influence that brand properties exert on buying decisions. Yoo et al.,(2000) further notes that brand loyalty has the power to influence consumers to continue buying the same product . Brand equity help customers to interpret, process and store huge quantities of information about products and brands. These brand dimensions influence on consumers' confidence in purchasing decision to the past experience or familiarity with the brand features. So, Brand equity is an important factor that influence the purchasing intension of the consumers. When the brand equity is higher it higher the Purchasing intension on to buy a product of a certain brand more and repeatedly (Jing et al, 2012).

\section{METHODOLOGY}

\subsection{Research Framework}

The model developed by Aeker (1991) presented in figure 3.1 is used to conceptualize the theoretical framework of the study. The model shows the dimensions of brand equity for selected mobile brand.

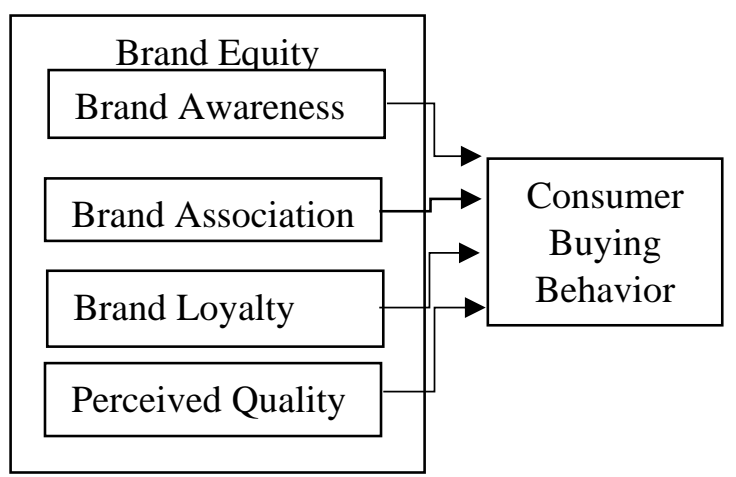

Figure 1. Conceptual Model

Based on the relationships proposed between each dimension of brand equity and consumer buying behavior, the following hypothesis are formulated to answer the research question of what extent each 
dimension of brand equity affects consumer buying behavior.

$\mathrm{H}_{1}=$ There is a positive impact of Brand awareness on consumer buying behavior.

$\mathrm{H}_{2}=$ There is a positive impact of Brand association on consumer buying behavior.

$\mathrm{H}_{3}=$ There is a positive impact of Brand Loyalty on consumer buying behavior.

$\mathrm{H}_{4}=$ There is a positive impact of perceived quality on consumer buying behavior.

$\mathrm{H}_{5}=$ There is a positive impact of Brand equity on consumer buying behavior.

\subsection{Sample}

Convenience sampling technique was used to collect the data as no any register of mobile users available in Sri Lanka. The survey method was employed for 380 mobile brand users in Mattakkuliya and Jinthupitiya areas in Colombo. The study is cross sectional in time horizon.

\subsection{Instrumentation}

The questionnaire was designed based on the dimensions presented by Aeker. Data collected through physically distributing questionnaires and through online. Brand equity model included brand awareness, brand association, brand loyalty and perceived quality. Section 01 of the questionnaire covered the demographic factors and section 02 covers the brand equity dimensions and consumer buying behavior. The four brand awareness construct statements were adopted from the studies of Goi \& Fayrene (2011). The thirteen statements which comprise the statements of the brand association originated from the studies of Goi \& Fayrene (2011). The eight statements which comprise the statements of the brand loyalty originated from the studies of Bruno \& Dariusz (2014). The five perceived quality construct statements were adopted from the studies of Goi \& Fayrene (2011). The nine statements which comprise the statements of the consumer buying behavior originated from the studies of Kelly, along with Eldredge, Dalton \& Miller (2014). Certain important demographic factors that are relevant to this study incorporated to analyze whether these factors influence brand equity dimensions. The five questions covering the demographic characters of the respondents incorporated to this research. The five items that represents the Aeker's brand equity model were measured by using the five point Likert scale (1=strongly disagree to $5=$ strongly agree).

\section{RESULTS}

This research used multiple regression coefficients for the analysis. The data analysis for this study conducted through SPSS version 20. The study also tested the reliability of the instrument .Out of 380 questionnaires 368 were returned. Total questionnaires returned with blank responses made a response rate of $96.8 \%$. Incomplete questionnaires were taken to the analysis as they were $5.70 \%$ of total questionnaires by using mid-point scale. No any Outlier values identified in the study. Suitability of data Tested through multivariate assumptions; normality, linearity and 
Multicollinearity. The alpha reliability coefficients for brand awareness, brand association, brand loyalty, perceived quality $0.762,0.756,0.768$ and 0.733 respectively. These estimates of the internal consistency of the of the four dimensions brand awareness, brand association, brand loyalty and perceived quality of the research questionnaire, calculated using Cronbach's alpha coefficients were generally in a satisfactory level. Internal consistency for the brand awareness, brand association, brand loyalty and perceived quality scores was a score that was calculated as the sum of all the questions for a respondent. The correlation among brand awareness, brand association, brand loyalty and perceived quality had a satisfactory level in all the questions hence none of the questions were eliminated. The survey consisted with 368 participants of which $196(53.3 \%)$ were male and $172(46.7 \%)$ were females. The majority of the participants were 18-7 age and single. Most of the participants were students and Huawei brand users.

According to descriptive statistics it revealed that brand awareness, brand association, brand loyalty and perceived quality has the mean values of $3.18, \quad 3.44, \quad 3.35$ and 3.55 respectively indicating standard deviations $<1$ for all dimensions of brand equity (see table.1). This means most of the consumers moderately agree with the existing Huawei brand awareness and brand loyalty. Highly agree with existing Huawei brand loyalty and perceived quality.
Table 1. Descriptive Statistic

\begin{tabular}{|l|l|l|c|}
\hline Dimensions & N & Mean & $\begin{array}{l}\text { Standard } \\
\text { Deviation }\end{array}$ \\
\hline Brand Awareness & 368 & 3.18 & 0.659 \\
\hline Brand Association & 368 & 3.44 & 0.641 \\
\hline Brand Loyalty & 368 & 3.35 & 0.710 \\
\hline Perceived Quality & 368 & 3.55 & 0.733 \\
\hline
\end{tabular}

Table 2. Regression Model Summary

\begin{tabular}{|c|c|c|c|c|}
\hline Model & $\mathrm{R}$ & $\begin{array}{c}\mathrm{R} \\
\text { Square }\end{array}$ & $\begin{array}{c}\text { Adjusted } \\
\text { R Square }\end{array}$ & $\begin{array}{c}\text { Std. Error of } \\
\text { the Estimate }\end{array}$ \\
\hline 1 & $.694^{\mathrm{a}}$ & .482 & .476 & .406 \\
\hline
\end{tabular}

There is a 0.694 correlation between observed and predicted values of consumer buying behavior. The value of $\mathrm{R}^{2}$ of the regression model was 0.482 ., which means 48.2 percent of the total variance in the consumer buying behavior has been explained by the model.

Table 3. Summary result of each hypothesis tested

\begin{tabular}{|l|c|c|}
\hline \multirow{2}{*}{ Hypothesis } & \multicolumn{2}{|c|}{$\begin{array}{c}\text { Regression } \\
\text { coefficient }\end{array}$} \\
\cline { 2 - 3 } & $\boldsymbol{\beta}$ & $\mathbf{p}$ \\
\hline $\begin{array}{l}\text { H1= There is a positive impact of } \\
\text { brand awareness on consumer } \\
\text { Buying behavior. }\end{array}$ & 0.103 & 0.015 \\
\hline $\begin{array}{l}\text { H2= There is a positive impact of } \\
\text { brand association on consumer } \\
\text { Buying behavior. }\end{array}$ & 0.076 & 0.030 \\
\hline $\begin{array}{l}\text { H3= There is a positive impact of } \\
\text { brand loyalty on consumer } \\
\text { Buying behavior. }\end{array}$ & 0.278 & 0.000 \\
\hline $\begin{array}{l}\text { H4= There is a positive impact of } \\
\text { perceived quality On consumer } \\
\text { Buying behavior. }\end{array}$ & 0.182 & 0.000 \\
\hline $\begin{array}{l}\text { H5= There is a positive impact of } \\
\text { brand equity on consumer buying } \\
\text { behavior }\end{array}$ & 0.624 & 0.000 \\
\hline
\end{tabular}


The impact of independent variables on dependent variable was investigated and results in the table. 3 indicates positive impact of brand loyalty and its dimensions on consumer buying behavior variable $(p<0.05)$. Thus, all the hypotheses were accepted.

\section{DISCUSSION}

The outcome of the brand awareness, brand association, brand loyalty, perceived quality, brand equity which had a significant positive $\beta$ values $(\beta=0.103, \beta=0.076, \beta=0.278, \beta=0$ $.182, \beta=0.624, \mathrm{p}<0.05)$ implies that these four dimensions with an overall impact of brand equity contribute to positively impact on the consumer buying behavior based brand equity model. Therefore, the findings of this research were consistent with the brand equity framework of Aeker (1991). The findings were matched with the theoretical arguments given by Aeker (1991), Malik, et al. (2013). They argued that brand awareness is one of the most important factors in determining consumer buying behavior, and it leads to increased consumer buying behavior with positive impact. The findings related to brand association are matched with the theoretical arguments given by Yoo, Donthu et al (2000). Brand association is one of the most important factors in determining consumer buying behavior, and it leads to increased consumer buying behavior with positive impact on consumer preferences and choice in buying( Malik, Ghafoor, \& Iqbal, 2013).The findings related to brand loyalty are matched with the theoretical arguments given by
Ashraf, et al.(2017) and Sharma, et al, (2013).They argued that when brand loyalty is higher consumers' intension or behavior to repurchase a particular brand frequently higher and it has a positive impact on consumers to buy. Perceived quality findings are matched with the theoretical arguments given by Shaharuden et al. (2013), Kandasamy (2014). They argued that if the customers have a good perception about the quality of the product it will stimulate the consumers or individuals to buy a product from a certain brand. According to the above research findings and literature there is an overall impact of brand equity on consumer buying behavior. Therefore, this study related with the previous studies.

\section{CONCLUSION}

The findings of this research confirm that brand awareness, brand association, brand loyalty and perceived quality positive significant impact on consumer buying behavior of Huawei Brand in Colombo area. Additionally, in this study demographic variables such as gender, marital status, occupation, age cause for the variation in the mobile brand they use as Huawei brand is best demanded among males,18-27 age category, married, and private staff while Samsung is high demanded among females,18-27, singles and students. Therefore, strong brand equity allows Huawei Company to retain their customers and satisfy the needs of their customers in an effective way in order to increase their existing level of sales and profits. Brand equity can be increased by 
increasing Huawei brand recall, recognition, brand personality, organizational associations, purchase repetition, brand prioritizing, tendency to be loyal, performance, features, reliability, and product information through successful marketing efforts. The study concluded that Huawei brand managers' efforts should be mainly focused to improve brand equity in terms of brand awareness, brand association, brand loyalty and perceived quality to stimulate the consumer buying behavior.

Existing level of sales and profits can be enhanced by improving Huawei brand strengths and by getting maximum of their opportunities and can stimulate the sales by enhancing brand prioritizing among customers, paying attention to mobile advertisements, and introducing new updates and excellence customer services will stimulate brand loyalty. Improve the Huawei product performances, features, reliability and information create perceived quality. Providing some human characters like competence and toughness which enhances the brand recall. As brand awareness having the least impact it is recommended to stimulate impact on consumer buying behavior more by marketing brand stories and humanizing the brand.

Despite the contributions of this study and the implications, it includes some limitations which can contribute for the future researches. In this research the data was collected by employing convenience sample method. Hence, it could not represent the target population of this research. In order to generalize the results employ simple random sampling technique. This study was restricted only to the Mattakkuliya and Jinthupitiya areas where population is high in Colombo. Therefore, it is recommended capturing the other areas of Colombo and from other countries where Huawei brand is well established. The sample size of 380 used in this study could also be increased to examine effect of brand equity on consumer buying behavior based on Huawei in conclusion.

\section{REFERENCES}

Aaker, D. A. (1991). Managing Brand Equity.New York:The Free Press.

Akhtar, N., Ain, Q., Siddiqi, U., Ashraf, A., \& Latif, M. (2016). Impact of a Brand Equity on Consumer Purchase Decision in. International Review of Management and Business Research. 5(3).pp.808-816.

Ashraf, M., Naeem, M., \& Shahzadi, M. (2017). Impact of Branding on Consumer Buying Behavior: International Journal of Academic Research in Business and Social Sciences. 7 (7).pp592-603.

Baumgartner,H. and

Steenkamp,J.B.E.M.(1996).

Exploratory consumer buying behavior: Conceptualization and measurement. Internatio nal Journal of Research in Marketing.13(2) .pp.121-137.

Bruno,S.,\&Dabrowski,D.(2014).The effect of social media communication on consumer perceptions of brands. Journal of 
Marketing Communication.pp.126.

Businesswire(2020). Country and Industry Analysis, Sri Lanka telecommunications:2020.

Cecere, G., Mancinelli, S., Mazzanti, M., 2014. Waste prevention and social preferences:the role of intrinsic and extrinsic motivations. Ecol. Econ. 107, pp.163-176.

Central Bank of Sri Lanka(2010).Annual

Report.Colombo.

Chen,L.J \& Chen,H.H.(2011). Sustaining Client Relationships in the Contract Manufacturer OwnBrand Building Process: The Case of a Smartphone Firm. International Journal of Business and Management 6(7).pp.59-68.

Coldwell, J. (2001) Characteristics of a good customer satisfaction survey. u: Sheth J.N., Parvatiyar A., Shainesh G. [ur.] Customer Relationship Management, New Delhi: Tata McGraw-Hill, Pp. 193-199.

Claiborne,A.B. \& Sirgy,M.J.(2014). Self-Image Congruence as a Model of Consumer Attitude

Dailymirror (2018).Huawei Becomes Fastest Growing Smartphone in Sri Lanka.

Formation and Behavior: A Conceptual Review and Guide for Future Research. Academy of Marketing Science.pp.1-7.
O'Dea, S.(2020). Number of Smartphone users worldwide from 2016 to 2021.Statista.

Gunawardane, N. ( 2015). Impact of Brand Equity towards Purchasing Desition: A Situation on Mobile. Journal of Marketing Management. 3 (1).pp.100-117.

Goi,C.L., \& Fayrene,Y.L.C.(2011).Customer Based Brand Equity:A Literature Review. Journal of Arts Science \& Commerce. 11(1). pp.33-42.

Malik, M. E., Ghafoor, M. M., \& Iqbal, H. K. (2013). Importance of Brand Awareness and Brand Loyalty in assessing Purchase. International Journal of Business and Social Science..4(5).pp.167171.

Sharma, A., Bhola, S., Malyan, S., \& Patn, N. (2013). Impact of Brand Loyalty on Buying Behavior of Women. Global Journal of Management and Business Studies.3(7). pp.817-824.

Taylor,E.S. \& Tyler,J.H.(2012).The effect of evaluation on teacher performance. American Economic Review .102(7).pp.3628-3651.

Huawei Investment \& Holding Co., Ltd. (20 19)Annual report.

Hossain, M., \& Ahmed, K. (2018). Impact of brand equity on the buying behaviour of Millennials. International Journal of Business and Management Invention (IJBMI).7( 8).pp.47-54 
Kandasamy, C. (2014). Impact of Customer Brand Perceived Quality on Buying Intention. International Journal of Management and Social Science Research Review.1 (3).pp.1-5.

Jing,H.,Liu,X.,Wang,S.,\&Yang,Z.(20 12). The role of brand image congruity in Chinese consumers' brand preference. Journal of Product \& Brand Managemen.t 21(1). pp.26-34.

Keller, K. L. (2013). Strategic Brand Management: Building, Measuring, and Managing Brand Equity. Pearson.

Kelly ,S., Eldredge ,S.A., Dalton,E.D. \& Miller,L.E.(2014). HealthInformation Behavior: An Initial Validity Portfolio for Active and Passive Measures. Communication Research Reports. 31(2).pp.171-182.

Keller, K.L \& Kotler, P.(2012). Marketing Management.14th Edition, Pearson Education.

Ketavath, a. (2018). Customer Satisfaction On Mobile Phone Services.United States: Lulu Publications

Leuthesser,L. (1998).Defining, measuring and manufacturing brand equity. Texas: Marketing Science Institute.
Madichie, N. (2009). Consumer Behavior: Buying, Having, and Being. $8^{\text {th }}$ ed. Emerald Group Publihing Ltd.

Nasri,W. \& Charfeddine,L.(2012). Factors affecting the adoption of Internet banking in Tunisia: An integration theory of acceptance model and theory of planned behavior. The Journal of High Technology Management Research.23(1).pp.1-14.

Nilmini,W.M.I.(2014). Impact of brand equity on brand preference towards purchase intention: a case of motor vehicle market in Sri Lanka.

Sullivan \& Frost (2016). A Country \& Industry Ana lysis- Sri Lanka Telecomm unications .

Yoo, B., Donthu , N., \& Lee, S. (2014). An Examination of Selected Marketing Mix Elements and Brand Equity. Journal of the Academy of Marketing Science.28 (2).pp.195-211.

Lee, Back, J., \& Joon, K. (2010). Reexamination of attendee-based brand equity. Tourism Management.29(2).pp.331-344 